Case Report

\title{
Techno-Economic Evaluation of Biodiesel Production from Waste Cooking Oil-A Case Study of Hong Kong
}

\section{Sanjib Kumar Karmee ${ }^{1}$, Raffel Dharma Patria ${ }^{2}$ and Carol Sze Ki Lin ${ }^{1, *}$}

1 School of Energy and Environment, City University of Hong Kong, Tat Chee Avenue, Kowloon, Hong Kong; E-Mail: sanjibkarmee@gmail.com

2 Department of Chemical and Biomolecular Engineering, the Hong Kong University of Science and Technology, Clear Water Bay, Kowloon, Hong Kong; E-Mail: rdpatria@ust.hk

* Author to whom correspondence should be addressed; E-Mail: carollin@cityu.edu.hk; Tel.: +852-3442-7497; Fax: +852-3442-0688.

Academic Editor: James H. Clark

Received: 1 January 2015 / Accepted: 13 February 2015 / Published: 18 February 2015

\begin{abstract}
Fossil fuel shortage is a major challenge worldwide. Therefore, research is currently underway to investigate potential renewable energy sources. Biodiesel is one of the major renewable energy sources that can be obtained from oils and fats by transesterification. However, biodiesel obtained from vegetable oils as feedstock is expensive. Thus, an alternative and inexpensive feedstock such as waste cooking oil (WCO) can be used as feedstock for biodiesel production. In this project, techno-economic analyses were performed on the biodiesel production in Hong Kong using WCO as a feedstock. Three different catalysts such as acid, base, and lipase were evaluated for the biodiesel production from WCO. These economic analyses were then compared to determine the most cost-effective method for the biodiesel production. The internal rate of return (IRR) sensitivity analyses on the WCO price and biodiesel price variation are performed. Acid was found to be the most cost-effective catalyst for the biodiesel production; whereas, lipase was the most expensive catalyst for biodiesel production. In the IRR sensitivity analyses, the acid catalyst can also acquire acceptable IRR despite the variation of the WCO and biodiesel prices.
\end{abstract}

Keywords: biodiesel; economic evaluation; equipment costs; capital investment costs; internal rate of return (IRR) 


\section{Introduction}

The continuous increase in energy demand is contributing to petroleum-based oil depletion. In addition, inherent particle emitted by conventional fossil fuel combustion process has contributed towards the environmental pollution. Therefore, renewable energy sources are required for satisfying the energy demand. In this regard, biodiesel is considered a viable alternative fuel. As an energy source, biodiesel can reduce the emission level of the pollutants [1]. In addition, biodiesel is non-toxic and biodegradable, and it can be used along with conventional petroleum based fuels to create blends [2].

Commercially, biodiesel is produced using vegetable oils as feedstocks and chemical (acid/base) catalysts. Technically, it has been proven that the biodiesel production using vegetable oils as feedstock gives biodiesel with more than $90 \%$ yield [3]. Vegetable oils are costly. Therefore, biodiesel price using vegetable oil as feedstock ( $\pm \$ 1.01 / \mathrm{L})$ is expensive [4]. The oil feedstock contributes approximately $90 \%$ of the biodiesel production cost [5]. Therefore, an alternative feedstock is required for the cost-effective production of biodiesel.

In the above context, nonedible plant oils are used for the preparation of biodiesel [3,6,7]. Recently, lipid from food waste is used as a nonedible resource for biodiesel production [8,9]. Along this line, one of the alternative feedstock to produce biodiesel is waste cooking oil (WCO). WCO can be converted into biodiesel by transesterification [10-12]. Food supply will not be affected by the use of non-edible materials such as WCO as feedstock for biodiesel preparation. Therefore, the food versus fuel debate can be avoided. From the economics point of view, the use of WCO as a feedstock for biodiesel production is economically favorable $(\$ 0.36 / \mathrm{L})$ [13]. Furthermore, it is estimated that 20,000 tons of WCO are generated in Hong Kong each year [14]. This data suggests that large quantities of waste cooking oil are available in Hong Kong. Along this line, WCO can be utilized as a beneficial and viable feedstock for the biodiesel production in Hong Kong.

In the above context, in this report economic analyses of the biodiesel production from WCO in Hong Kong with different catalysts are performed. Acid, base and lipase as the catalysts were evaluated for this techno-economic study. The techno-economic studies using these catalysts for biodiesel production processes were carried out using Aspen Plus as simulation tool.

\section{Results and Discussion}

\subsection{Process Results}

The biodiesel production capacities for all three processes using acid, base and lipase as catalysts are 8 kiloton/year. In general, WCO contains around 2\% to $7 \%$ free fatty acids (FFA) and therefore, it is assumed in this study that the WCO contains 6\% FFA [15]. The reaction conditions of all the three catalysts are kept in optimum conditions, such as the reaction temperature at $50{ }^{\circ} \mathrm{C}$ for the lipase and at $65{ }^{\circ} \mathrm{C}$ for the acid and base catalysts. Molar ratio of oil to methanol was 1:4. The reaction time was $6 \mathrm{~h}$ for chemical and enzymatic reactions. Although the reaction time for biodiesel production using base catalyst is usually shorter than $6 \mathrm{~h}$, it is assumed that the reaction time for all of the chemical and enzymatic reactions in this study was $6 \mathrm{~h}$ to achieve higher biodiesel conversions and equal biodiesel production capacities for all processes ( 8 kiloton/year). In addition, $5 \mathrm{wt} \%$ of chemical catalysts (acid/base) and $10 \mathrm{wt} \%$ of enzyme were used for the reactions. In this optimum reaction conditions, 
biodiesel conversions for all three catalysts are above 90\% [16-18]. In addition, Novozym-435 catalyzed biodiesel can be recycled for 200 times without obvious decrease in biodiesel yield [18]. Therefore, it is assumed that the biodiesel yield in this study is $100 \%$ and the lipase reusability is 200 times. The acid, base and lipase catalyzed biodiesel production processes were analyzed in accordance with the optimum conditions. The obtained results of each individual process are presented in Table 1.

Table 1. Operating conditions and simulation results using chemical and enzyme catalysts.

\begin{tabular}{cccc}
\hline \multirow{2}{*}{ Components } & \multicolumn{3}{c}{ Catalyst } \\
\cline { 2 - 4 } & Base & Acid & Enzyme \\
\hline Reaction temperature $\left({ }^{\circ} \mathrm{C}\right)$ & 65 & 65 & 50 \\
Molar ratio (oil:methanol = 1:x) & 4 & 4 & 4 \\
Lipase recyclability (times) & - & - & 200 \\
\hline Feed streams per day & & & \\
\hline Waste cooking oil (L) & $26,848.90$ & $26,848.90$ & $26,848.90$ \\
Catalyst (kg) & $1,206.72$ & $1,206.72$ & 12.07 \\
Methanol (L) & $4,339.70$ & $4,339.70$ & $4,339.70$ \\
\hline Product streams per day & \multicolumn{3}{|}{} \\
\hline Biodiesel (100\%) (kg) & $24,242.42$ & $24,242.42$ & $24,242.42$ \\
Glycerol (kg) & $2,469.18$ & $2,469.18$ & $2,469.18$ \\
Biodiesel conversion (\%) & 100.00 & 100.00 & 100.00 \\
\hline
\end{tabular}

\subsection{Economic Assessment}

Several assumptions were made for the techno-economic assessment. The equipment cost, raw material cost, biodiesel and glycerol prices are estimated in accordance with the reported processes [13,18-21]. According to these reports, the total equipment costs (TEC) for the biodiesel production process for each individual catalyst are calculated (Table 2).

Table 2. Total equipment costs (TEC).

\begin{tabular}{|c|c|c|c|c|c|c|c|}
\hline \multirow{2}{*}{ Equipment } & \multicolumn{3}{|c|}{ Amount } & \multirow{2}{*}{ Unit Cost (USD) } & \multicolumn{3}{|c|}{ Total Cost (USD) } \\
\hline & Base & Acid & Enzyme & & Base & Acid & Enzyme \\
\hline Tank $\left(100 \mathrm{~m}^{3}\right)$ & 7 & 6 & 6 & $\$ 66,478.00$ & $\$ 465,346.00$ & $\$ 398,868.00$ & $\$ 398,868.00$ \\
\hline $\begin{array}{c}\text { Splitter, mixer } \\
\text { (double-arm sigma) }(15 \mathrm{~kW})\end{array}$ & 4 & 2 & 1 & $\$ 56,550.00$ & $\$ 226,200.00$ & $\$ 113,100.00$ & $\$ 56,550.00$ \\
\hline Reactor $\left(15 \mathrm{~m}^{3}\right)$ & 5 & 4 & 1 & $\$ 88,906.00$ & $\$ 444,530.00$ & $\$ 355,624.00$ & $\$ 88,906.00$ \\
\hline $\begin{array}{l}\text { Separator (decanter) } \\
\text { (bottom driven } 0.6 \mathrm{~m} \text { diameter) }\end{array}$ & 4 & 3 & 2 & $\$ 13,769.00$ & $\$ 55,076.00$ & $\$ 41,307.00$ & $\$ 27,538.00$ \\
\hline Extraction column, distillation & 4 & 4 & 1 & $\$ 169,971.00$ & $\$ 679,884.00$ & $\$ 679,884.00$ & $\$ 169,971.00$ \\
\hline & & & & TEC & $\$ 1,871,036.00$ & $\$ 1,588,783.00$ & $\$ 741,833.00$ \\
\hline
\end{tabular}

In Table 2, the amount of each specific equipment used for the biodiesel production processes with different catalysts was determined from the process flow diagrams of biodiesel production (Schemes 1-3). Meanwhile, the size of each piece of equipment was calculated and approximated from the biodiesel 
production capacities per batch. It is assumed in this study that the plant working days are 330 days, the working time is $15 \mathrm{~h}$ per day, and two biodiesel batches are produced each day.

The capital investment cost (CIC) and specific investment cost (SIC) for each biodiesel production process using different catalysts are estimated. The capital investment cost (CIC) is the sum of total capital cost (TCC) and working capital, while the specific investment cost (SIC) is the CIC divided by the biodiesel production capacity per year. The CIC and SIC are calculated with respect to the TEC. There are several categories involved in calculating the CIC and SIC [4]. The CIC and SIC for each catalyst are calculated (Table 3 ).

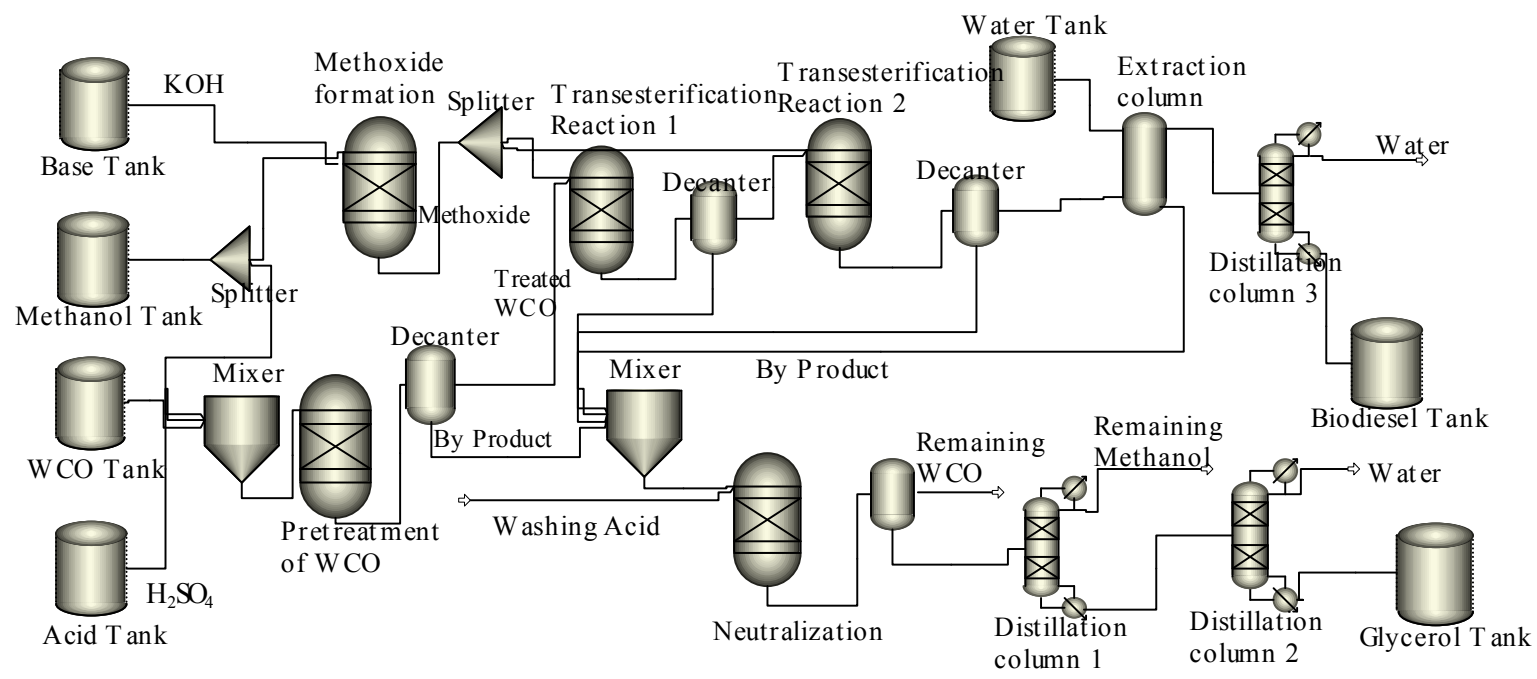

Scheme 1. Biodiesel production process using base catalyst.

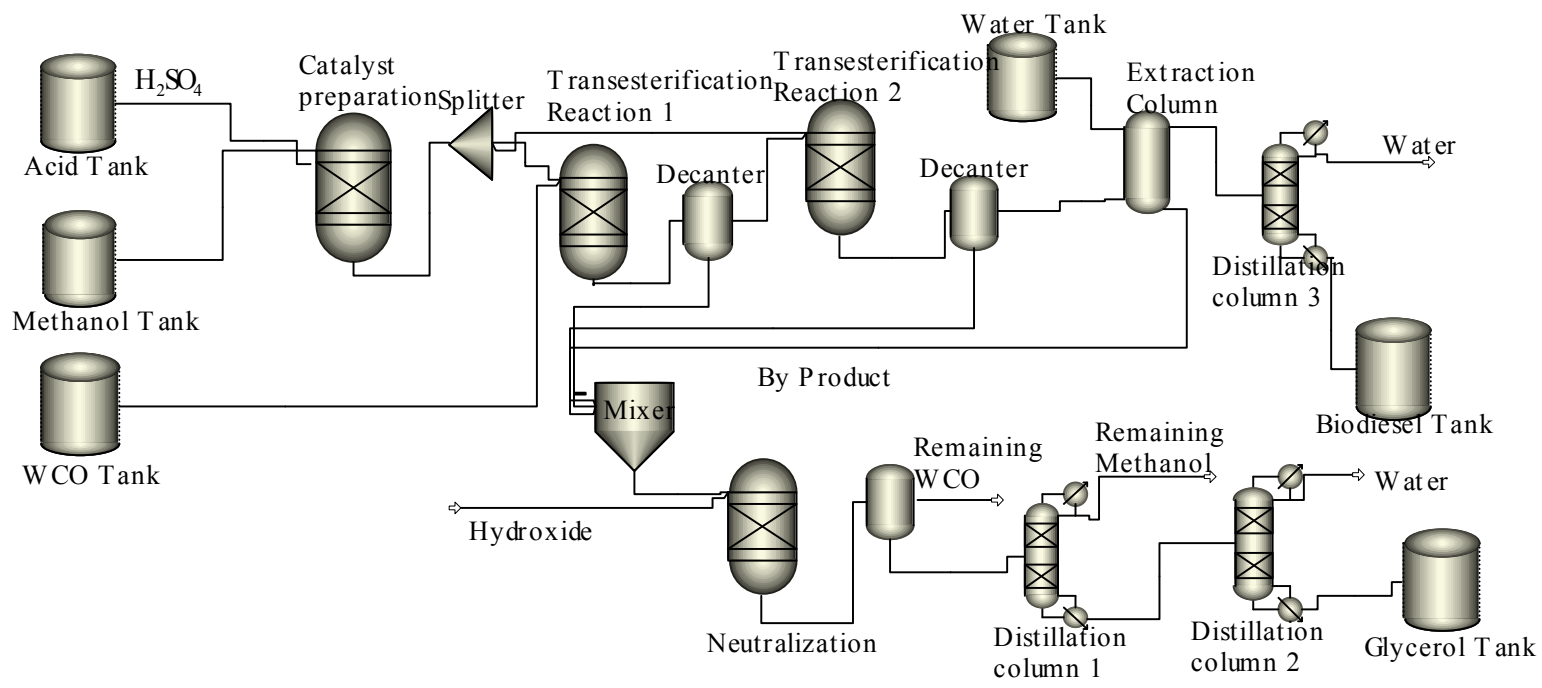

Scheme 2. Biodiesel production process using acid catalyst. 


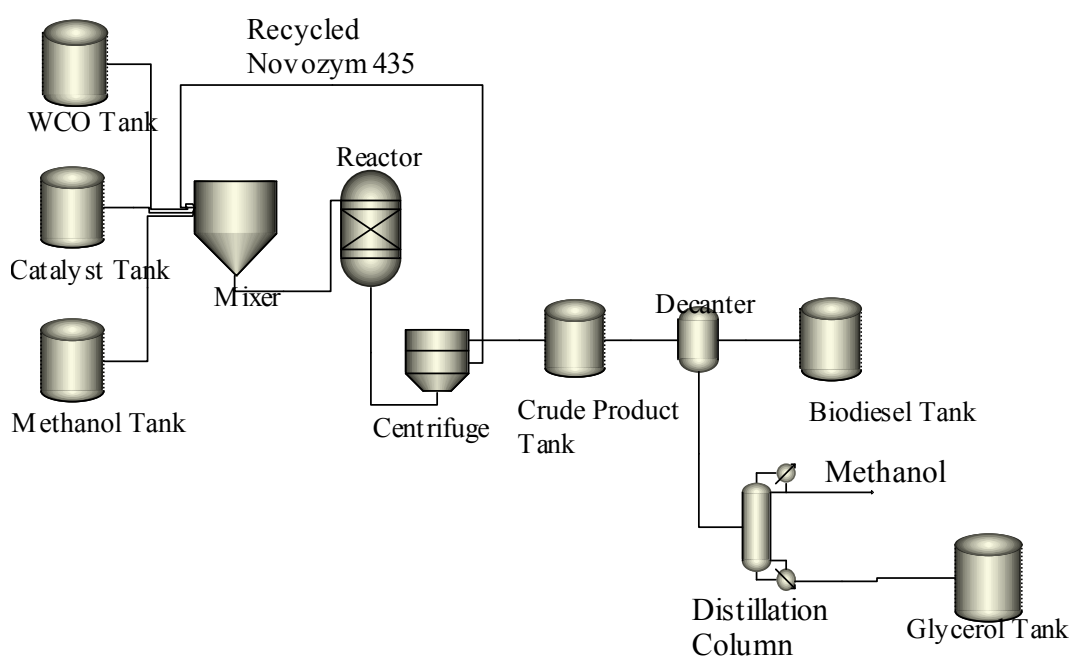

Scheme 3. Biodiesel production process with enzyme catalyst.

Table 3. Capital investment cost (CIC).

\begin{tabular}{ccccc}
\hline \multirow{2}{*}{ Capital Investment Category } & Percentage of TEC (\%) & \multicolumn{2}{c}{ Cost (USD) } & Enzyme \\
\cline { 2 - 5 } Total equipment cost (TEC) & 100 & Base & Acid & $\$ 741,833.00$ \\
Equipment delivery cost & 10 & $\$ 1,871,036.00$ & $\$ 1,588,783.00$ & $\$ 74,183.30$ \\
Installation cost & 20 & $\$ 374,207.20$ & $\$ 317,756.60$ & $\$ 148,366.60$ \\
Instrumentation \& control & 10 & $\$ 187,103.60$ & $\$ 158,878.30$ & $\$ 74,183.30$ \\
Piping & 20 & $\$ 374,207.20$ & $\$ 317,756.60$ & $\$ 148,366.60$ \\
Electrical system & 15 & $\$ 280,655.40$ & $\$ 238,317.45$ & $\$ 111,274.95$ \\
Buildings & 15 & $\$ 280,655.40$ & $\$ 238,317.45$ & $\$ 111,274.95$ \\
Service facilities & 25 & $\$ 467,759.00$ & $\$ 397,195.75$ & $\$ 185,458.25$ \\
Land acquisition & 10 & $\$ 187,103.60$ & $\$ 158,878.30$ & $\$ 74,183.30$ \\
Yard improvement & 10 & $\$ 187,103.60$ & $\$ 158,878.30$ & $\$ 74,183.30$ \\
Engineer training & 30 & $\$ 561,310.80$ & $\$ 476,634.90$ & $\$ 222,549.90$ \\
Legal expenses & 10 & $\$ 187,103.60$ & $\$ 158,878.30$ & $\$ 74,183.30$ \\
Contingency & 15 & $\$ 280,655.40$ & $\$ 238,317.45$ & $\$ 111,274.95$ \\
& Total capital cost (TCC) & $\$ 5,426,004.40$ & $\$ 4,607,470.70$ & $\$ 2,151,315.70$ \\
& Working capital & $25 \%$ of TCC & $25 \%$ of TCC & $25 \%$ of TCC \\
& Capital investment cost (CIC) & $\$ 6,782,505.50$ & $\$ 5,759,338.38$ & $\$ 2,689,144.63$
\end{tabular}

The biodiesel production cost (BPC) is estimated. There are several categories included in the calculations of BPC [4]. The biodiesel production cost for each catalyst is shown in Table 4. The breakdown figure for each category of the BPC with WCO as a feedstock for each catalyst is shown in Figure 1. The raw material and utilities for acid and base catalysts only contributes for $70 \%-71 \%$ of total costs; while in the case for lipase it contributes for $85 \%$ of total costs (Figure 1). The raw material and utilities cost while using vegetable oil as a feedstock contributes for around $90 \%$ of the total costs [5]. This indicates that utilization of WCO as a low cost feedstock reduced the production cost of biodiesel. 
Table 4. Biodiesel production cost (BPC).

\begin{tabular}{|c|c|c|c|c|}
\hline \multirow{2}{*}{ Category } & \multirow{2}{*}{ Unit Cost (USD) } & \multicolumn{3}{|c|}{ Cost (USD) } \\
\hline & & Base & Acid & Lipase \\
\hline \multirow[t]{2}{*}{ Raw material cost } & $\$ 0.57$ (base), $\$ 0.48$ (acid) & $\$ 5,008,424.12$ & $\$ 4,250,217.89$ & $\$ 7,098,606.93$ \\
\hline & $\$ 0.88($ enzyme)/L WCO & & & \\
\hline Glycerol revenues & $\$ 160.00 /$ ton & $\$ 130,372.92$ & $\$ 130,372.92$ & $\$ 130,372.92$ \\
\hline Electricity (assuming $60 \mathrm{kWh} /$ ton of biodiesel produced & $\$ 0.15 / \mathrm{kWh}$ & $\$ 72,000.00$ & $\$ 66,000.00$ & $\$ 48,000.00$ \\
\hline \multicolumn{5}{|l|}{ for base catalyst, $55 \mathrm{kWh} /$ ton for acid catalyst, } \\
\hline Labor (assuming 15 employees for base catalyst, & $\$ 50,000 /$ employee/year & $\$ 750,000.00$ & $\$ 700,000.00$ & $\$ 600,000.00$ \\
\hline \multicolumn{5}{|l|}{14 employees for acid catalyst, and 12 employees for lipase) } \\
\hline Maintenance and operational costs $(\mathrm{M} \& \mathrm{O})$ & $10 \%$ of TEC & $\$ 187,103.60$ & $\$ 158,878.30$ & $\$ 74,183.30$ \\
\hline Plant overhead costs & $50 \%$ of labor and $\mathrm{M} \& \mathrm{O}$ & $\$ 468,551.80$ & $\$ 429,439.15$ & $\$ 337,091.65$ \\
\hline \multirow[t]{2}{*}{ Depreciation } & Straight-line depreciation over & $\$ 124,735.73$ & $\$ 105,918.87$ & $\$ 49,455.53$ \\
\hline & 15 -year factory life & & & \\
\hline General expenses & $25 \%$ of labor and $\mathrm{M} \& \mathrm{O}$ & $\$ 234,275.90$ & $\$ 214,719.58$ & $\$ 168,545.83$ \\
\hline Property insurance costs & $5 \%$ of TEC & $\$ 93,551.80$ & $\$ 79,439.15$ & $\$ 37,091.65$ \\
\hline \multirow[t]{4}{*}{ Contingency } & $10 \%$ of labor, $\mathrm{M} \& \mathrm{O}$ & $\$ 140,565.54$ & $\$ 128,831.75$ & $\$ 101,127.50$ \\
\hline & and plant overhead costs & & & \\
\hline & Biodiesel production cost (BPC) & $\$ 6,948,835.57$ & $\$ 6,003,071.75$ & $\$ 8,383,729.46$ \\
\hline & Biodiesel production cost/ton & $\$ 868.60$ & $\$ 750.38$ & $\$ 1,047.97$ \\
\hline
\end{tabular}

WCO: Waste cooking oil; $\mathrm{M} \& \mathrm{O}$ : Maintenance and operational.

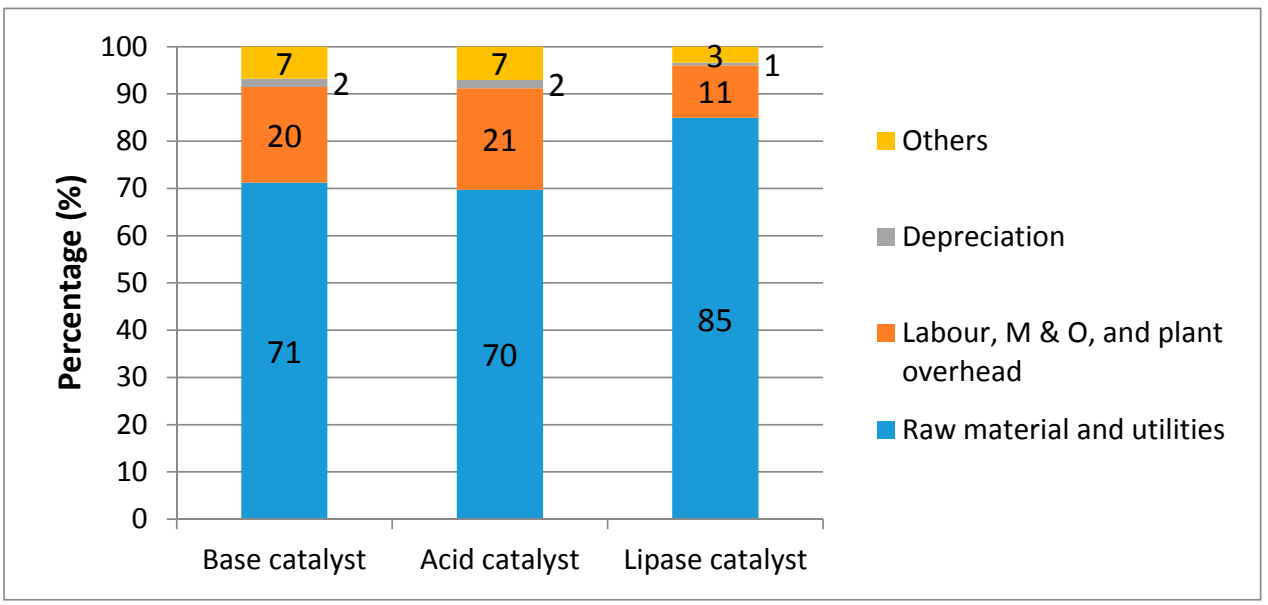

Figure 1. Biodiesel production cost (BPC) breakdown for each catalyst with waste cooking oil (WCO) as a feedstock.

\subsection{Sensitivity Analysis}

In the sensitivity analysis, the prices of WCO and biodiesel are varied to determine the correlation of the prices with the internal rate of return (IRR). The minimum IRR for a new investment in an established market is $16 \%$ [4]. The first three years are the capital investments and the first-year production has only $50 \%$ of the full production amount capacity, while the 4 th years onwards rose to $100 \%$ of total production capacity. There is a $25 \%$ taxation of the gross profit and annual increase of $7 \%$ of biodiesel production cost and biodiesel selling price. For the WCO price variation, the reference biodiesel price is $\$ 1.01 / \mathrm{L}$ 
(the biodiesel price with vegetable oil as feedstock). The IRR sensitivity analysis for the WCO price variation for each catalyst is shown in Figure 2. For the biodiesel price variation, the reference WCO price in Hong Kong is $\$ 0.36 / \mathrm{L}$ [13]. The IRR sensitivity analysis for the biodiesel price variation for acid, base and lipase is shown in Figure 3.

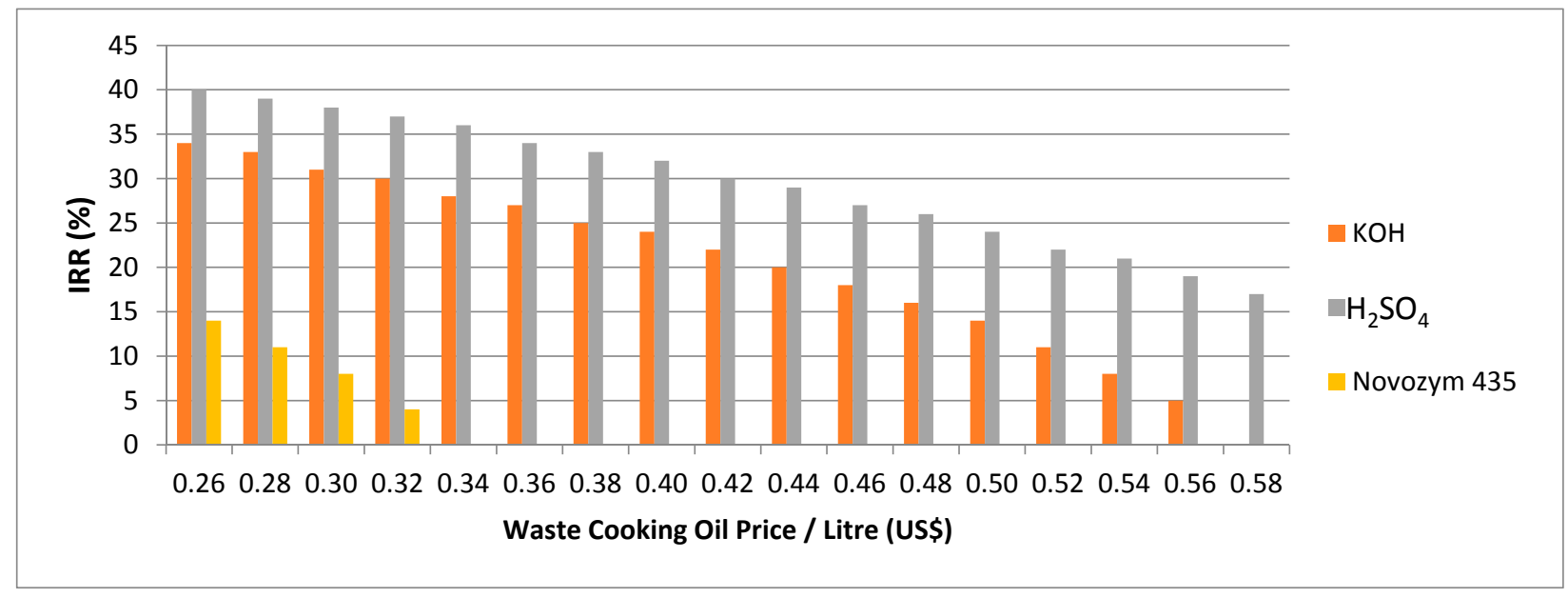

Figure 2. Internal rate of return (IRR) sensitivity analysis with WCO price variation.

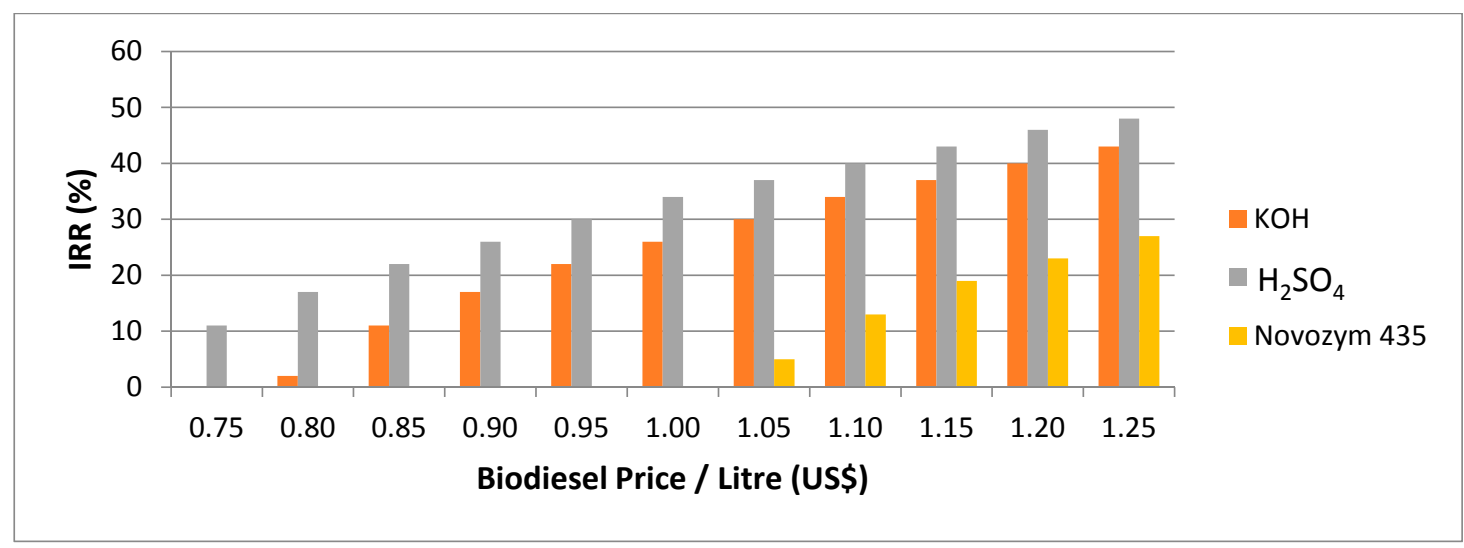

Figure 3. IRR sensitivity analysis with biodiesel price variation.

Acid catalyst was found to be the most cost-effective for the biodiesel production in Hong Kong (Figures 2 and 3). The acceptable WCO price for the acid catalyst is below $\$ 0.58$, and the acceptable biodiesel price is above $\$ 0.80$ (Figures 2 and 3). On the other hand, the acceptable WCO price for the base catalyst is below $\$ 0.48$, and base catalyzed process and enzyme catalyzed process have acceptable biodiesel price above $\$ 0.90$ and above $\$ 1.15$ respectively (Figures 2 and 3). This means that biodiesel production processes using acid and base catalysts can adapt with the variation in the WCO and biodiesel prices.

\section{Process Design and Case Study}

\subsection{Background of the Case Study}

Hong Kong is a small city with a total area of $1104 \mathrm{~km}^{2}$. In 2010 Hong Kong's diesel demand was 1408 kiloton/year [22,23]. It is estimated that the diesel consumption in 2014 is approximately 776 kiloton/year in Hong Kong [23]. The diesel price had been increasing from 2004 to 2012 and the 
diesel price in 2012 was $\$ 1.6 / \mathrm{L}$ [24]. The Hong Kong Government has implemented a mandatory policy to use $1 \%-5 \%$ of biodiesel as a blend in petroleum diesel [25]. Due to low mandatory biodiesel blending requirement, a small biodiesel production plant with a production capacity of 8 kiloton/year of biodiesel should be sufficient to produce the required amount of biodiesel for the overall consumption in Hong Kong. Therefore, this paper focuses on the techno-economic studies for a "biodiesel production plant" with a capacity of 8 kiloton/year.

\subsection{Biodiesel Production Process Using Chemical Catalysts}

For biodiesel production using a base catalyst $(\mathrm{KOH})$, the WCO is pretreated with the methanol and sulphuric acid $\left(\mathrm{H}_{2} \mathrm{SO}_{4}\right)$ as catalyst. Then, remaining methanol is reacted with a base catalyst $(\mathrm{KOH})$ to produce methoxide. In the pretreatment process, esterification reaction is performed to convert the free fatty acid in the WCO into fatty acid methyl ester or biodiesel [26]. The obtained mixture after pretreatment is transferred into a decanter to separate the treated $\mathrm{WCO}$ and the water by product. The treated WCO is then transferred into the first reactor, in which the treated WCO is transesterified with methoxide. Subsequently, the product of this reaction is decanted, and after separation of glycerol the obtained filtrate is transferred into a second reactor. In the second reactor, methoxide is added for the second transesterification process. The reaction mixture of this process is decanted. The byproduct glycerol is filtered, leaving the biodiesel, base catalyst $(\mathrm{KOH})$, and remaining glycerol in the filtrate. A stream of water and the filtrate are transferred into an extraction column.

The remaining methanol, $\mathrm{KOH}$, and remaining glycerol are extracted by water, while the biodiesel is separated. Then the biodiesel is transferred into a distillation column to make it dry by removing the remaining moisture. The obtained pure biodiesel is then stored in the biodiesel tank. On the other hand, all the remaining substances such as WCO, methanol, glycerol, and $\mathrm{KOH}$ in the reaction are transferred into a reactor for the neutralization process. After neutralization the remaining WCO is decanted; while the remaining methanol and water are distilled into two separated distillation columns. Then, the pure glycerol is stored in a tank. The schematic base catalyzed biodiesel production process is presented in Scheme 1.

The acid catalyzed biodiesel production process does not follow the same mechanism as the base catalyzed process; and it does not require any pretreatment of WCO. Thus, the methoxide formation reactor is replaced with a catalyst preparation reactor to mix the methanol with acid catalyst $\left(\mathrm{H}_{2} \mathrm{SO}_{4}\right)$. The biodiesel production process using an acid catalyst is shown in Scheme 2.

\subsection{Biodiesel Production Process Using Lipase}

Lipases are extensively used as an alternative to chemical catalysts [27,28]. The production of biodiesel using lipase as a catalyst involved fewer unit operations as compared to the acid and base catalyzed processes. The WCO is reacted with methanol in the presence of lipase (Novozym-435) to form biodiesel and glycerol. The product of the transesterification reaction is transferred into a centrifuge to separate the lipase from the crude product containing biodiesel and glycerol. The lipase is then recycled for the subsequent transesterification reaction. The obtained reaction mixture is transferred into a decanter to separate the byproduct glycerol and remaining methanol from the biodiesel. The pure biodiesel is stored in the biodiesel tank; while, the glycerol is distilled from the methanol and stored in 
a glycerol tank. The schematic diagram of the biodiesel production process using lipase is presented in Scheme 3.

\section{Conclusions}

In this study, biodiesel production cost in Hong Kong from WCO as a feedstock is estimated. The use of acid and base catalysts for the biodiesel production are found to be less expensive ( $\$ 0.80$ and $\$ 0.90$ ) than the average biodiesel price in Hong Kong (\$1.01). Acid catalyzed method is the most cost-effective production process. On the other hand, application of lipase as a catalyst is found to be expensive (\$1.15). In addition, production of biodiesel using acid and base as catalysts can withstand variations from the $\mathrm{WCO}$ and biodiesel prices.

\section{Acknowledgments}

Sanjib Kumar Karmee is grateful to the School of Energy and Environment, City University of Hong Kong for a postdoctoral fellowship under the Graduate Teaching Assistant (GTA) scheme.

\section{Author Contributions}

Raffel Dharma Patria conducted the techno-economic studies using Aspen Plus; Sanjib Kumar Karmee and Raffel Dharma Patria analysed the simulation results and contributed to the writing of the manuscript; and Carol Sze Ki Lin assisted in the revision of manuscript. The final version was read and approved by all authors.

\section{Conflicts of Interest}

The authors declare no conflict of interest.

\section{References}

1. Demirbas, A. Importance of biodiesel as transportation fuel. Energy Policy 2002, 35, 4661-4670.

2. Demirbas, A. Progress and recent trends in biodiesel fuels. Energy Convers. Manag. 2009, 50, 14-34.

3. Meher, L.C.; Sagar, D.V.; Naik, S.N. Technical aspects of biodiesel production by transesterification-A review. Renew. Sustain. Energy Rev. 2006, 10, 248-268.

4. Skarlis, S.; Kondili, E.; Kaldellis, J.K. Small-scale biodiesel production economics: A case study focus on Crete Island. J. Clean. Prod. 2012, 20, 20-26.

5. Chhetri, A.B.; Watts, K.C.; Islam, M.R. Waste cooking oil as an alternate feedstock for biodiesel production. Energies 2008, 1, 3-18.

6. Karmee, S.K.; Chadha, A. Preparation of biodiesel from crude oil of Pongamia pinnata. Bioresour. Technol. 2005, 96, 1425-1429.

7. Karmee, S.K.; Chandna, D.; Ravi, R.; Chadha, A. Kinetics of base-catalyzed transesterification of triglycerides from Pongamia oil. J. Am. Oil Chem. Soc. 2006, 83, 873-877.

8. Karmee, S.K.; Lin, C.S.K. Lipids from food waste as feedstock for biodiesel production: Case Hong Kong. Lipid Technol. 2014, 26, 206-209. 
9. Karmee, S.K.; Lin, C.S.K. Valorisation of food waste to biofuel: Current trends and technological challenges. Sustain. Chem. Process. 2014, doi:10.1186/s40508-014-0022-1.

10. Enweremadu, C.C.; Mbarawa, M.M. Technical aspects of production and analysis of biodiesel from used cooking oil-A review. Renew. Sustain. Energy Rev. 2009, 13, 2205-2224.

11. Karmee, S.K.; Mahesh, P.; Ravi, R.; Chadha, A. Kinetic study of the base-catalyzed transesterification of monoglycerides from Pongamia oil. J. Am. Oil Chem. Soc. 2004, 81, 425-430.

12. Ma, F.; Hanna, M.A. Biodiesel production: A review. Bioresour. Technol. 1999, 70, 1-15.

13. No Smooth Ride for Biodiesel. Available online: http://www.scmp.com/article/973788/no-smoothride-biodiesel (accessed on 1 January 2015).

14. A Food Waste and Yard Waste Plan for Hong Kong. Available online: http://www.enb.gov.hk/ en/files/FoodWastePolicyEng.pdf (accessed on 1 January 2015).

15. Gerpen, J.V. Biodiesel processing and production. Fuel Process. Technol. 2005, 86, 1097-1107.

16. Wang, Y.; Ou, S.; Liu, P.; Zhang, Z. Preparation of biodiesel from waste cooking oil via two-step catalyzed process. Energy Convers. Manag. 2007, 48, 184-188.

17. Kiakalaieh, A.T.; Amin, N.A.S.; Mazaheri, H. A review on novel processes of biodiesel production from waste cooking oil. Appl. Energy 2013, 104, 683-710.

18. Chen, H.; Ju, H.; Wu, T.; Liu, Y.; Lee, C.; Chang, C.; Chung, Y.; Shieh, C. Continuous production of lipase-catalyzed biodiesel in a packed-bed reactor: Optimization and enzyme reuse study. J. Biomed. Biotechnol. 2011, 2011, 1-6.

19. Indicative Chemical Prices A-Z. Available online: http://www.icis.com/chemicals/channel-infochemicals-a-z/ (accessed on 1 January 2015).

20. Biodiesel Production Chemicals. Available online: http://utahbiodieselsupply.com/biodieselchemicals. php (accessed on 11 October 2014).

21. Peters, M.S.; Timmerhaus, K.; West, R.E. Plant Design and Economics for Chemical Engineers, 5th ed.; McGrawHill: New York, NY, USA, 2002.

22. Hong Kong Geographic Data. Available online: http://www.landsd.gov.hk/mapping/en/ publications/total.htm (accessed on 1 January 2015).

23. Hong Kong SAR, China-Road Sector Diesel Fuel Consumption. Available online: http://www. indexmundi.com/facts/hong-kong-sar,-china/road-sector-diesel-fuel-consumption (accessed on 1 January 2015).

24. Wagner, A. International Fuel Prices 2012/2013, 8th ed.; Deutsche Gesselschaft für Internationale Zusammenarbeit (GIZ): Bonn, Germany, 2013; pp. 1-63.

25. Biofuel Maker Pushes Product Use in Market. Available online: http://www.scmp.com/business/ companies/ article/1341490/biofuel-maker-pushes-product-use-market (accessed on 1 January 2015).

26. Araujo, C.D.M.; Andrade, C.C.; Silva, E.S.; Dupas, F.A. Biodiesel production from used cooking oil: A review. Renew. Sustain. Energy Rev. 2013, 27, 445-452.

27. Karmee, S.K. Lipase catalyzed synthesis of ester-based surfactants from biomass derivatives. Biofuels Bioprod. Biorefin. 2008, 2, 144-154.

28. Karmee, S.K. Biocatalytic synthesis of ascorbyl esters and their biotechnological applications. Appl. Microbiol. Biotechnol. 2009, 81, 1013-1022.

(C) 2015 by the authors; licensee MDPI, Basel, Switzerland. This article is an open access article distributed under the terms and conditions of the Creative Commons Attribution license (http://creativecommons.org/licenses/by/4.0/). 